\title{
Foreword: JMO special issue on self-employment/freelancing
}

\section{Nigel Meager}

$\mathrm{T}$ his special issue of the journal explores aspects of self-employment and freelance working. These are forms of work which are of increasing interest to researchers (and indeed policymakers) at international ${ }^{1}$ and national levels. There are several key reasons for this, which we explore below.

\section{A GROWING PHENOMENON}

First, although there are major differences between countries, as Organisation for Economic Co-operation and Development (OECD) data in Figure 1 show, self-employment or own-account working (outside agriculture) now accounts for a substantial share of the employed workforce in many industrialised countries (in some countries as many as a quarter of those in work are self-employed, and self-employment accounts for more than one in 10 of the workforce in around two-thirds of OECD countries).

Moreover, it has been growing in the majority of these countries in the last decade or so (Figure 2), and the underlying trend seems to be an upward one. This does undoubtedly challenge the postwar consensus that self-employment was a diminishing archaic form of work, largely confined to agriculture, manual craft activities and a few liberal professions. However, as the paper by Bridge in this special issue argues, from a longer term historical perspective, it is waged employment which should perhaps be seen as the aberration.

\section{SELF-EMPLOYMENT AS A POSITIVE OR NEGATIVE SOCIAL AND ECONOMIC PHENOMENON?}

Second, there is an ongoing and long-standing discussion in both the academic and the policy literature about 'good' and 'bad' self-employment, and many of the papers in the special issue contribute to this discussion in different ways (with Bridge's paper highlighting a key aspect of the debates around self-employment which are emerging in recent literature, namely its 'desirability').

Thus, the literature raises the question of whether self-employment (and growth in self-employment) should be seen as:

- A positive phenomenon, associated with entrepreneurship and contributing to economic and employment growth, and something to be supported through policy including as a supposedly positive option for the unemployed ${ }^{2}$ and excluded groups in the workforce.

- A more problematic feature of the modern labour market, potentially associated with precarious employment conditions, poor job quality and low earning levels, and in the extreme case a lack of

Institute for Employment Studies, Brighton, United Kingdom

For overview of recent developments at European level, see European Commission (2010) and Hatfield (2015).

2 For a recent review of initiatives in EU member states to activate the unemployed to enter self-employment and start their own enterprises, see European Commission (2014).

Corresponding author: tui.mckeown@monash.edu 
Foreword: JMO special issue on self-employment/freelancing

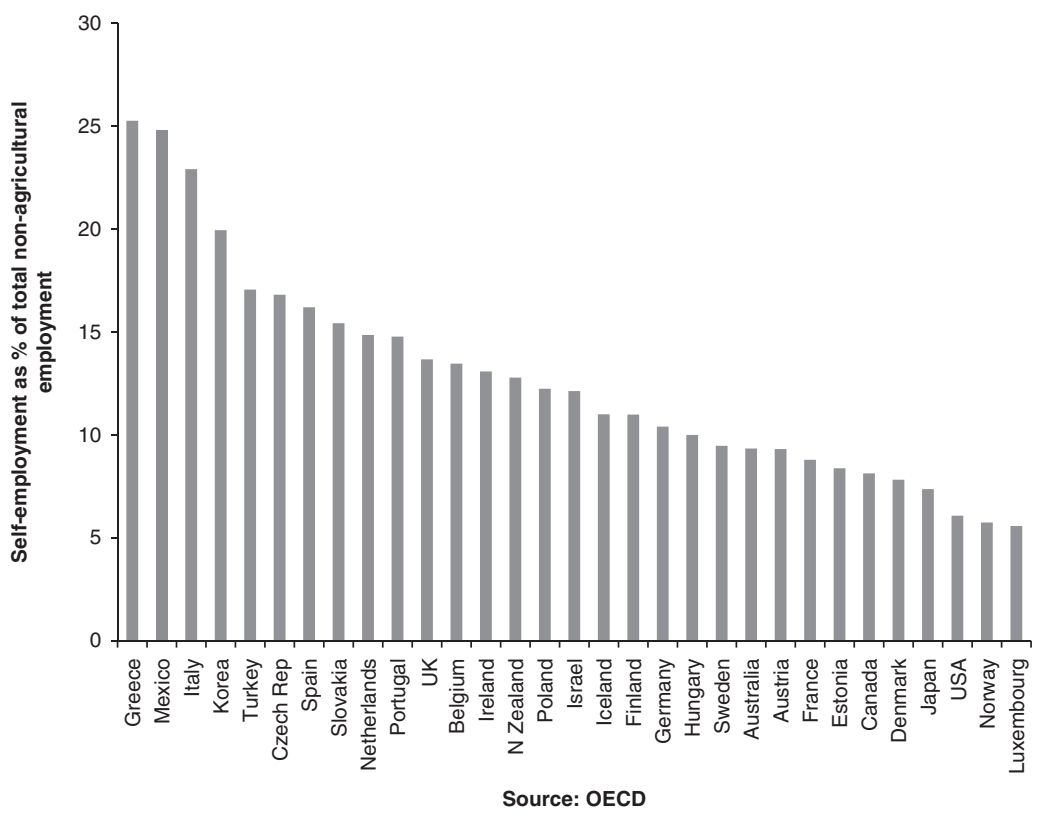

Figure 1. Nonagricultural self-employment rates, 2013 (OECD countries)

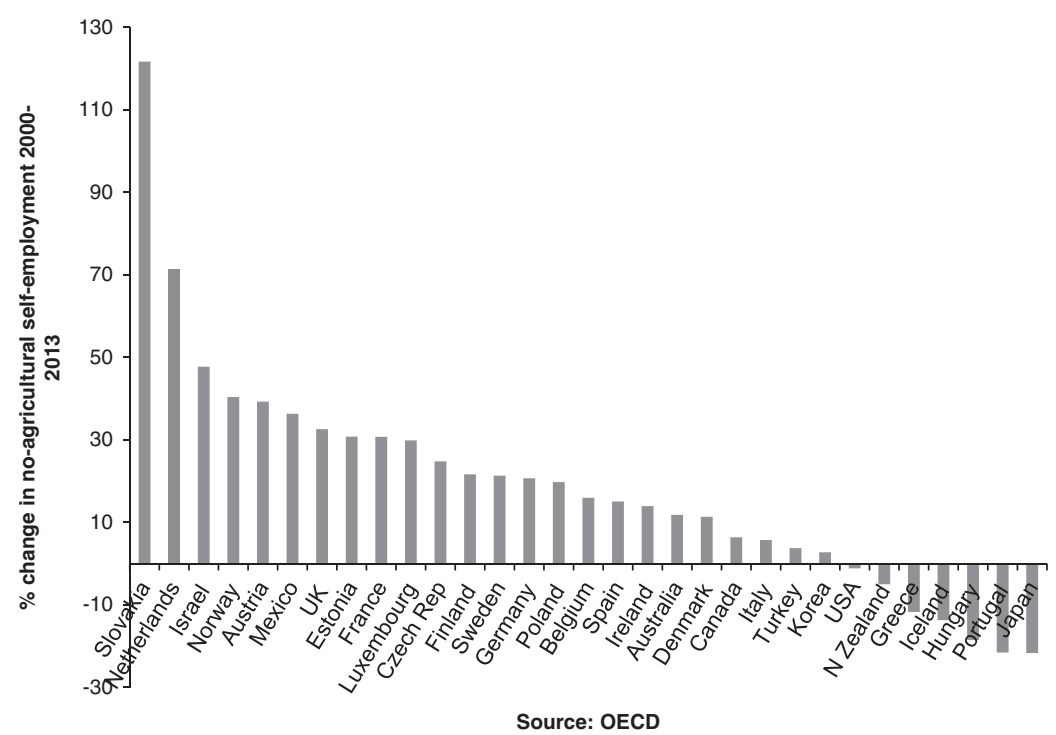

Figure 2. Change in Self-employment, 2000-2013 (OECD countries)

security, human capital development and exclusion from aspects of social protection. The debate about 'sham' or 'bogus' self-employment (or 'disguised wage-employment') ${ }^{3}$, where individuals are notionally 'self-employed' but in practice highly dependent on an enterprise and without the normal

3 'Sham' self-employment, under which employees are recorded as self-employed to enable their employers to circumvent tax and employment regulations is defined by the ILO as 'when the employer treats a worker in such a way as to conceal his/her true legal status as an employee': International Labour Office (2006). 
protections afforded to waged employees, reflects concerns about these more negative implications of (some parts of) the self-employment phenomenon ${ }^{4}$.

- Some mixture of the two: as some authors have argued's 'self-employment' is perhaps an unhelpful aggregate category not only in statistical terms, but also in terms of legal and policy definitions (as explored by the paper by Wynn in this special issue), encompassing as it does a wide spectrum of forms and conditions of work. In practice 'self-employment' is not a homogeneous category. At one extreme it includes genuine entrepreneurs, small business owner/proprietors, and autonomous craft workers or members of the liberal professions, and at the other extreme it includes highly dependent workers in sectors including construction and personal services who have little or no autonomy in their working lives or terms and conditions of employment. In the middle is a range of more ambiguous categories of work where it can be difficult to judge whether the appropriate status is genuinely 'self-employed' or not: Boegenhold's paper in this special issue addresses many of these boundary questions, proposing a category of 'hybrid self-employed', whose characteristics differ significantly from more traditional self-employment modes as well as from dependent or wage employment. These more ambiguous employment statuses also touch on several new employment forms in the so-called 'gig economy' (Donovan, Bradley, \& Shimabukuro, 2016), involving workers whose employment relationships (with both the contracting enterprise and the ultimate consumer of services/goods) are mediated by a variety of new information technology platforms: drivers for the Uber taxi service are a well-known and controversial example (see the discussion in Eisenbray $\&$ Mishel, 2016), which Leighton examines in her paper.

\section{THE QUALITY OF SELF-EMPLOYED WORK}

Third, there is a debate about the working conditions and job quality of the self-employed and how these relate to their subjective well-being and job satisfaction. Thus it is commonly observed in many countries that, on average, and compared with employees, the self-employed work longer hours ${ }^{6}$, earn less ${ }^{7}$ and enjoy in many respects poorer working conditions and job security (Pedersini \& Coletto, 2010). On the other hand, it is also observed in many data sets that the self-employed report higher levels of job (and life) satisfaction than comparable employees ${ }^{8}$. Typically, this apparent paradox is explained through some kind of selection effect, namely that those who enter self-employment are more likely to value the autonomy, independence and flexibility associated with 'being their own boss', and these factors tend to offset the more negative aspects of job quality in self-employment ${ }^{9}$. However, there remain a number of issues unresolved in this debate, not least that it is also clear from the literature that a significant proportion of the self-employed are not 'volunteers' in the sense of choosing

4 For further discussions of false/bogus self-employment and the boundaries between self-employment and dependent employment, see, for example Bergström and Storrie (2003), Böheim and Muehlberger (2006), Jorens (2008), European Parliament (2013).

5 Thus for example, Meager (2008) notes '... self-employment encompasses a wide range of working modes of different degrees of autonomy, some of which conform much more closely than others to the "entrepreneur" of the economic models. It is, therefore, implausible to model the relationship between the economic cycle and self-employment as a single aggregate, when that aggregate is composed of diverse parts, each responding differently to changes in the economic and institutional environment'.

6 See, for example the discussion of working time patterns of the self-employed in Pedersini and Coletto (2010).

7 See Hamilton (2000) and Koellinger, Mell, Pohl, Roessler, and Treffers (2015). As Koellinger et al. note 'When entrepreneurs say that they are "not in it for the money", the data seem to support them'.

8 See Blanchflower (2000), Hundley (2001), Taylor (2004), Benz and Frey (2008).

9 See for example, two studies which use European-level data to examine this question of job satisfaction: Lange (2012) and Millán, Hessels, Thurik, and Aguado (2013). 
self-employment over alternative forms of work; rather many of them (particularly in times of high unemployment and economic crisis) may be 'pushed' into self-employment by lack of alternatives in wage employment ${ }^{10}$. It is not obvious, for this latter group at least, that a psychological preference for autonomy will play the same role in explaining job satisfaction differences between the self-employed and employees ${ }^{11}$. Again, some of the papers in this special issue throw new light on aspects of these debates, notably the papers by Blomme et al. (focussing on the daily lives of the self-employed, and the interface between their work and non-work lives), and Syrett (who explores aspects of the well-being of freelance workers, and the extent to which the institutional setting provides appropriate support for that well-being).

However, it is also worth highlighting that this literature typically relies on rather limited measures of 'job quality', or measures which are more appropriate to employees than to the jobs of the selfemployed. In this context (and if I might be excused for drawing attention to my own work) it is interesting that a recent national level (UK) study (Baumberg \& Meager, 2015) found, using data from a series of UK surveys going back to the 1980s, more consistency between the job quality and satisfaction indicators. Indeed on most indicators that study found that self-employment involved a higher intrinsic job quality and job satisfaction than working as an employee (although self-employed people work harder, with less training, and with less satisfaction about their job security). However, the study also found considerable heterogeneity among the self-employed, with the self-employed-withstaff working harder than sole traders, but having more satisfaction with various aspects of their job; additionally it found that the quality of self-employment had deteriorated in the years since the financial crisis. There is a strong case for more work on this topic, both extending the UK evidence to other countries for comparison purposes, and making use of new data sources on self-employment and job quality which are now beginning to become available.

\section{LOOKING AHEAD TO A MORE NUANCED VIEW OF SELF-EMPLOYMENT}

The papers in this special issue all contribute in important ways to this new and growing field of scholarship. Whatever we call it (self-employment, contracting, freelancing, entrepreneurship, etc.), this large, growing and blurry-edged segment of the labour market is likely to attract increasing interest from scholars in the social and managerial sciences. What emerges from the papers in the present issue is that simple characterisations of these forms of work as 'good'/'bad', 'desirable'/'undesirable', 'high quality'/'low quality', 'autonomous'/'dependent', are increasingly unhelpful - rather a more nuanced approach which confronts the evidence of a diverse, growing and changing group from different theoretical and empirical perspectives is required, and these papers all, in their different ways, take further steps in this direction. The papers from McKeown and Boegenhold in particular draw our attention to the diversity and complexity of working models embodied in the simple terms such as 'self-employed', 'independent contractor', 'freelancer', and McKeown proposes a new 'consilience' methodology for reconciling and drawing new information from the varied perspectives on these groups offered by different data sets.

So far, so good. However, I would argue that researchers in this field have only begun to scratch the surface of the new and complex phenomenon that is 'self-employment' in all its different guises, which appears increasingly likely to become an established part of the social and labour market landscape of

10 There is a large literature on the balance between 'necessity' and 'opportunity' entrepreneurship, and the relative balance between the two as motivators for entry to self-employment. See for example Dawson, Henley, and Latreille (2009).

11 In this context, it is relevant to note that Binder and Coad (2013) find a relationship between job satisfaction and whether an individual is a 'necessity' or an 'opportunity' entrepreneur with the latter generally recording higher levels of satisfaction than the former. 
the 21 st century in developed economies. The state of knowledge on this topic still has a number of key gaps to be filled by research which goes beyond the papers in the current volume. Several developments are needed, in my view.

\section{THE STATISTICAL BASE}

First, we need data sets which better reflect the nuances and heterogeneity of 'self-employment' as described above. In most countries, the official labour market statistics go little further than counting whether someone identifies themselves as 'self-employed' and whether they employ anyone else. While it is possible to say a lot more about the self-employed from these data sets, and to compare them with employees on a vast range of personal and job-related characteristics, the initial classification into 'self-employed' or 'employee' status on which all this kind of analysis depends, leaves a lot to be desired. Encouragingly, this is now beginning to be recognised, and the International Labour Office (ILO) which sets standards in this area through the International Classification of Status in Employment (ICSE-93) is embarked on a major revision of these standards, with a concern to capture and monitor various types of vulnerable or precarious self-employment in particular. As Hunter (2015) notes:

'A variety of new contractual arrangements that aim to increase flexibility in the labour market are leading to increasing uncertainty about the boundary between self-employment and paid employment, while at the same time generating a need for statistical information to monitor the impact of these arrangements'.

In particular, among the key issues currently being addressed in the work to revise ICSE-93 are (see Hunter, 2015, op. cit):

'The relevance and usefulness of maintaining a distinction between paid employment and self-employment as a dichotomous pair of high level categories, given the wide range of analytical uses of these categories, and the increasing number of types of employment arrangement that do not fit comfortably into either category'.

'The boundary between self-employment and paid employment, particularly with respect to owner-managers of incorporated enterprises and dependent contractors'.

While the final outcome of this revision process is not expected until 2018 at the earliest (the wheels of international collaboration on statistical standards turn relatively slowly it seems), this approach seems to be evolving into a classification in which two key factors taken into account to segment people in work are:

(a) The type of economic risk to which the job-holder is exposed: this generates a hierarchy with employment for pay at one end, and employment for profit at the other.

(b) The type of authority over establishments and other workers which the job incumbents have or will have: similarly this generates a hierarchy with dependent workers at one end, and fully independent workers at the other.

In this kind of approach, it is explicitly acknowledged that some types of job can have the characteristics of both paid employment and self-employment, or where there is some ambiguity about the employment arrangements: this might apply, for example, to the owner-managers of incorporated businesses, to contractors who are dependent on larger organisations to a greater or lesser extent and to some categories of family workers. These categories would need to be aggregated with others, either according to the economic risk criterion, or according to the authority criterion, depending on the purpose of the analysis.

As and when these changes take place, the quality of statistical data available to researchers on selfemployment, freelancing and myriad related forms of 'non-standard' work, will be greatly enhanced. 
We will also, for the first time, have official labour market data which can conceptually accommodate many of the new forms of work emerging in what is variously described as the 'gig economy' or the 'sharing economy'.

\section{INSTITUTIONS AND SUPPORT STRUCTURES: A NEW RESEARCH AGENDA}

The second main lacuna in this research field is the relative lack of work being undertaken on the institutional frameworks and support structures which are necessary for a labour market in which a growing number of people spend significant proportions of their working life, not in a standard employee relationship, but in some form of self-employment, freelancing or independent contract work. Most current policy is premised on the assumption that self-employment equates to entrepreneurship, business and economic growth and higher overall employment levels, along with independence and autonomy for the self-employed individuals. As a result, the focus of policy is too often solely on the unconditional encouragement of and support for people, including unemployed and disadvantaged groups in the labour market, to enter self-employment. As we have argued above, the 'entrepreneurship' story is likely to apply only to a subset of the self-employed and much evidence suggests that for a possibly growing segment $^{12}$ of the self-employed, their working lives are characterised by low and unstable incomes, precariousness and dependence. What is needed is research which focusses on these groups, but which goes beyond simply documenting their characteristics and charting their experiences. Rather it should move towards identifying the kinds of support structures, and institutional arrangements which will ameliorate the negative aspects of these forms of work, and make it possible for people whose life-course trajectories take them through periods (possibly long periods) of self-employment, to enjoy decent incomes, working conditions, career progression and secure retirements. Where should such research focus? Scholars' preferences will undoubtedly reflect their own national and disciplinary perspectives but my priorities would include

- Human capital and skills development. If a growing segment of the workforce is spending some or all of its working life in work, but outside wage employment in some form of self-employment, contracting or freelancing, we need to ask where and how such workers will both acquire and update the skills, both professional and business skills, which they need to thrive in this environment. Who provides and pays for the freelancer or independent professional's training and skills enhancement, which if s/he was an employee would be provided by the employer? Official statistics for nearly all countries $^{13}$, confirm that the self-employed are much less likely (typically half as likely) as employees to be engaged in work-related training or skills development in any given period, and much less likely to be engaged in further study of any kind. Remedying this deficit, and providing structures and incentives for self-employed workers of all types to acquire and improve the skills they need, is a clear policy priority in a world of rapid technological, market and organisational change, in which 'lifelong learning' is a sine qua non for professional and personal development.

- Social security and welfare entitlement, with a particular focus on pensions and later life. As previous research has noted (see the discussion in Baumberg \& Meager, 2015), the self-employed have more polarised incomes than employees, and one impact of being self-employed (after controlling for other characteristics) is to increase a person's likelihood of low incomes. More importantly, there is some evidence of a 'scarring effect' from periods of self-employment, in the sense that having had

12 As we argue in Baumberg and Meager (2015), in the UK at least, following the financial crisis of 2007, not only has self-employment grown to record levels, but the quality of self-employment appears to have deteriorated, while the median incomes of the self-employed have fallen rapidly and there has been a record growth in the numbers of part-time self-employed (contrary to the traditional 'entrepreneur' model of the small business owner with long-working hours).

13 See the European data in Hatfield (2015), for example, and the discussion in Meager, Martin, and Carta (2011). 
significant spells of self-employment in the working life can have a negative impact on income prospects later in life. As Meager (2008, p. 200) notes, '... the presence of self-employed spells in the previous work history does increase chances of poverty, low savings levels and poor pension entitlement in later life'. The inadequacy of the pensions and social security systems in many countries to accommodate the needs of self-employed people is well-documented in many countries (see, e.g., Frankus \& Fachinger, 2012; Fachinger \& Frankus, 2015).

- Employment rights and the development of a new approach which extends some of the protections which employees take for granted, to those 'self-employed' in the grey zone between employee status and genuine entrepreneurial independence (the 'hybrid' workers of Boegenhold), with a particular focus on the new contractual forms emerging in the 'gig economy' or 'sharing economy'. As Donovan, Bradley, and Shimabukuro (2016) note (in the US context, but the case is universal) there is a clear research agenda emerging to identify: what, if any, types of protections and benefits should be extended to freelance workers of this kind, who should be responsible for enforcing such protections or providing such benefits, and (in the absence of a clear 'employer') how should access to benefits be structured?

\section{References}

Baumberg, B., \& Meager, N. (2015). Job quality and the self-employed: Is it still better to work for yourself? In A. Felstead, D. Gallie, \& F. Green (Eds), Unequal Britain at work: The evolution and distribution of intrinsic job quality in Britain (pp. 105-129). Oxford: Oxford University Press.

Benz, M., \& Frey, B. (2008). Being independent is a great thing: Subjective evaluations of self-employment and hierarchy. Economica, 75(298), 362-383.

Bergström, O., \& Storrie, D. (Eds.) (2003). Contingent employment in Europe and the United States. Cheltenham: Edward Elgar Publishing.

Binder, M., \& Coad, A. (2013). Life satisfaction and self-employment: A matching approach. Small Business Economics, 40, 1009-1033.

Blanchflower, D. (2000). Self-employment in OECD countries. Labour Economics, 7(5), 471-505.

Böheim, R., \& Muehlberger, U. (2006). Dependent forms of self-employment in the UK: Identifying workers on the border between employment and self-employment. Retrieved from http://ftp.iza.org/dp1963.pdf.

Dawson, C., Henley, A., \& Latreille, P. (2009). Why do individuals choose self-employment? (IZA Discussion Paper no 3974, Bonn: IZA). Retrieved from http://ftp.iza.org/dp3974.pdf.

Donovan, S., Bradley, D., \& Shimabukuro, J. (2016). What does the Gig Economy mean for workers? (CRS Report R44365). Washington: Congressional Research Service. Retrieved from https://www.fas.org/sgp/crs/misc/R44365.pdf.

Eisenbray, R., \& Mishel, L. (2016). Uber business model does not justify a new 'independent worker' category. Employment Policy Institute. Retrieved March 17, 2016 from http://www.epi.org/publication/uber-businessmodel-does-not-justify-a-new-independent-worker-category/.

European Commission (2010). Self-employment in Europe 2010. European Employment Observatory Review, September 2010, Directorate-General for Employment, Social Affairs and Equal Opportunities. Retrieved from http://ec.europa.eu/social/main.jsp?catId=738\&langId=en\&pubId=576\&type=2\&furtherPubs=yes

European Commission (2014). Activating jobseekers through entrepreneurship: Start-up incentives in Europe. European Employment Observatory Review, October 2014, Directorate-General for Employment, Social Affairs and Equal Opportunities. Retrieved from http://ec.europa.eu/social/main.jsp?catId=738\&langId=en\&pubId= 7730\&type $=2 \&$ furtherPubs=yes

European Parliament (2013). Social protection rights of economically dependent self-employed workers study. European Parliament Policy Department A. Retrieved from http://bookshop.europa.eu/is-bin/INTERSHOP. enfinity/WFS/EU-Bookshop-Site/en_GB/-/EUR/ViewPublication-Start?PublicationKey=BA3013643.

Fachinger, U., \& Frankus, A. (2015). Self-employment and pensions - is old age poverty the inevitable dark side of an entrepreneurial society? In J. Bonnet, M. Dejardin, \& D. Garcia Perez de Lema (Eds.), Exploring the entrepreneurial society. Institutions, behaviours and outcomes. Cheltenham: Edward Elgar. 
Frankus, A., \& Fachinger, U. (2012). Self-employed people and old age provision - Is old age poverty coming back to Germany? (Discussion Paper 06/2012). Vechta: Fachgebiet Ökonomie und Demographischer Wandel, Institut für Gerontologie.

Hamilton, B. (2000). Does entrepreneurship pay? An empirical analysis of the returns to self-employment. Journal of Political Economy, 108, 604-631.

Hatfield, I. (2015). Self-employment in Europe. London: Institute for Public Policy Research. Retrieved from http:// www.ippr.org/files/publications/pdf/self-employment-Europe_Jan2015.pdf?noredirect=1.

Hundley, G. (2001). Why and when are the self-employed more satisfied with their work? Industrial Relations, 40(2), 293-316.

Hunter, D. (2015). Review of the International Classification of Status in Employment (ICSE). United National Department of Economic and Social Affairs: Statistics Division. Retrieved from http://unstats.un.org/unsd/class/ intercop/expertgroup/2015/AC289-35.PDF.

International Labour Office (2006). Employment Relationship Recommendation, 2006 (No. 198). Recommendation concerning the employment relationship. Adoption: Geneva, 95th ILC session, June 15, 2006.

Jorens, Y. (2008). Self-employment and bogus self-employment in the European construction industry: A comparative study of 11 member states. Report drafted by order of the European Social Partners for the Construction Industry (EFBWW and FIEC). Retrieved from http://www.efbww.org/pdfs/annex\%208\%20-\%20Brochure\%20part\%201\% 20\%5BEN\%5D.pdf.

Koellinger, P., Mell, J., Pohl, I., Roessler, C., \& Treffers, T. (2015). Self-employed but looking: A labour market experiment. Economica, 82(325), 137-161.

Lange, T. (2012). Job satisfaction and self-employment: autonomy or personality? Small Business Economics, 38(2), $165-177$.

Meager, N. (2008). Self-employment dynamics and 'Transitional Labour Markets': Some more UK Evidence. In R. Muffels (Ed.), Flexibility and employment security in Europe. Cheltenham: Edward Elgar.

Meager, N., Martin, R., \& Carta, E. (2011). Skills for self-employment (Evidence Report 31). UK Commission for Employment and Skills. August. Retrieved from http://dera.ioe.ac.uk/10135/1/evidence-report-31-skills-for-selfemployment.pdf.

Millán, J., Hessels, J., Thurik, R., \& Aguado, R. (2013). Determinants of job satisfaction: A European comparison of self-employed and paid employees. Small Business Economics, 40(3), 651-670.

Pedersini, R., \& Coletto, D. (2010). Self-employed workers: Industrial relations and working conditions. Dublin: Eurofound.

Taylor, M. (2004). Self-employment in Britain: When, who, what and why. Swedish Economic Policy Review, 11(2), 139-173. 